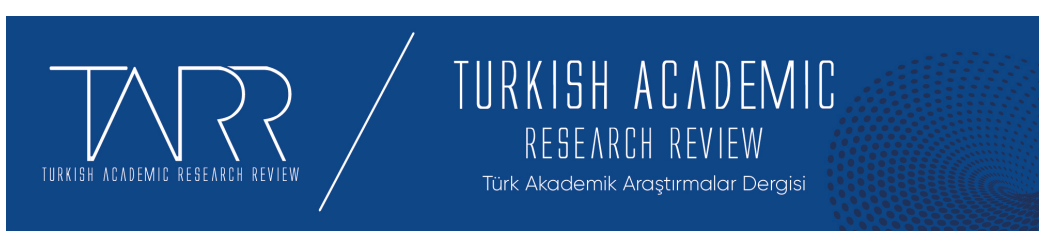

e-ISSN: 2602-2923 Yll/Year: 2021 Cilt/Volume: 6 Sayı/Issue: 2

\title{
Tasavvufta Rüya ile Amel ve Fıkıh Usulü Açısından Değerlendirilmesi
}

In Sufism Acting With Dream And The Evaluatıon In Terms Of Usul Al-Fiqh

\section{Derviș DOKGÖZ}

Dr., Malatya Milli Eğitim Müdürlüğü, ddokgoz44@hotmail.com, ORCİD:0000-0002-08910696

\begin{tabular}{r|l} 
Makale Bilgisi & Article Information \\
Makale Türü - Article Type & Araştırma Makalesi / Research Article \\
Geliş Tarihi - Date Received & 15 Mayıs / May 2021 \\
Kabul Tarihi - Date Accepted & 23 Haziran / June 2021 \\
Yayın Tarihi - Date Published & 25 Haziran / June 2021 \\
Yayın Sezonu & Nisan - Mayıs- Haziran \\
Pub Date Season & April - May - June
\end{tabular}

Atıf / Cite as: Dokgöz, D. (2021). Tasavvufta Rüya ile Amel ve Fıkıh Usulü Açısından Değerlendirilmesi/In Sufısm Acting With Dream And The Evaluation In Terms Of Usul Al-Fiqh. Turkish Academic Research Review, 6 (2), 523-543. Retrieved from https://dergipark.org.tr/tr/pub/tarr/issue/62824/937759

Intihal / Plagiarism: Bu makale, en az iki hakem tarafından incelenmiş ve intihal içermediği teyit edilmiştir. / This article has been reviewed by at least two referees and confirmed to include no plagiarism. https://dergipark.org.tr/tr/pub/tarr

Copyright (C) Published by Mehmet ŞAHIN Since 2016- Akdeniz University, Faculty of Theology, Antalya, 07058 Turkey. All rights reserved.

Turkish Academic Research Review - Türk Akademik Araştırmalar Dergisi 


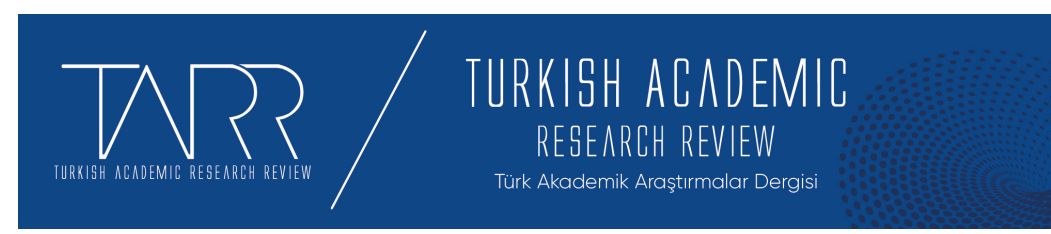

e-ISSN: 2602-2923 Yıl/Year: 2021 Cilt/Volume: 6 Sayı/Issue: 2

\author{
Tasavvufta Rüya ile Amel ve Fıkıh Usulü Açısından \\ Değerlendirilmesi \\ Derviş DOKGÖZ
}

$\ddot{O} \mathbf{z}$

Dini ilimler içerisinde rüya ile en çok ilgilenen alan tasavvuftur. Tasavvuf hayatında rüyalar, özellikle tasavvufa yeni katılan müritlerin manevi eğitim süreci olan seyr ü sülûk aşamasında büyük önem taşır. Zira bu süreç rüyalara göre yürütülür. Ancak rüyanın tasavvuftaki kullanımı sadece bu alan ile sınırlı değildir. Sûfîler hangi şehirde ikamet edeceklerinden, kimleri kendilerine mürit seçeceklerine varıncaya kadar birçok konuda rüyalardan faydalanmışlardır. Bazı sûfîlere rüyalarında Hz. Peygamber veya diğer önde gelen sûfilerce çeşitli görevler tevdî edilmiştir. Yine bir kısım rüyalarda Hz. Peygamber veya tasavvuf büyüklerinden dua ve zikirler öğrenilmiştir. Bazı rüyalarda ise sûfîlere yaptıkları bir davranışın hatalı olduğu yönünde uyarılar yapılmış, düzeltilmesi istenmiştir. Sûfîlerce anlatılan rüyaların birçoğunda ise vefat etmiş kimselerden ölüm ve sonrasında yaşananlara dair bilgiler öğrenilmek istenmiştir. Bunun yanında mutasavvıfların gördükleri bazı rüyalardan fikhî/amelî konulara dair hükümler çıkardıkları da görülmektedir. Buna göre rüyalar, bazen Hz. Peygamberden bir söz aktarımında araç olarak kullanılırken, bazen bir fikhî hükmün öğrenilmesi veya düzeltilmesinde, bazen de bir gaybî bilginin elde edilmesinde kullanılmaktadır. Bu makalede özellikle amelî sahada sonuçları olan rüyalardan örnekler aktarılarak, bunlara dair değerlendirmelerde bulunulmuştur. Ayrıca fikıh usulü açısından rüyaların amel edilme yönü ve bağlayıcılığı konusuna dair bilgiler verilmiştir. Fıkhî açıdan rüyalarla amel edilmesi konusunda genel kural, peygamberlerin rüyaları dışında hiçbir rüya ile herhangi bir şer‘î hüküm sabit olamaz. Yine mevcut bir şer‘̂̂ hüküm de rüya ile değiştirilemez, iptal edilemez. Ancak mubah alanlarda ve iyiliğe sevk etme, kötülüğü engelleme amacina işaret eden rüyalarla, rüyayı gören kişi amel edebilir. Ancak bu durumda bile bir zorunluluk bulunmamakta olup, kiși istemediği takdirde -bu alanlarda olsa dagördüğü rüya ile amel etmeyebilir.

Anahtar Kelimeler: F1kıh, F1kıh usulü, Rüya, Tasavvuf, Tabir.

\title{
In Sufism Acting With Dream And The Evaluation In Terms Of Usul Al-Fiqh
}

\begin{abstract}
Abstrac
Among the religious sciences, the field that is most interested in dreams is sufism. Dreams in the life of sufism, especially the spiritual education process of the new followers of sufism, are of great importance in the 'seyr ü sülûk' stage. Because this process applies according to dreams. However, the usage of dreams in sufism isn't limited to this field. Sufis have benefited from dreams in many subjects, from which city they will reside, to whom they will choose their followers. Some sufis were assigned duties by the Prophet or other leading sufis in their dreams. In some dreams, prayers and dhikrs were learned from Prophet Muhammad or pioneer sufis. In some dreams, the sufis were warned that their behavior was wrong, and they were asked to be corrected. In many of the dreams told by sufis, it was required to learn from the deceased people about death and what happened after death. In addition, it is known that sufis make judgments on fiqh / practice from some dreams they see.
\end{abstract}

Turkish Academic Research Review - Türk Akademik Araştırmalar Dergisi 
Accordingly, dreams are sometimes used as a means of conveying a hadith from the Prophet. It is sometimes used to learn or correct a fiqh rule, and sometimes to obtain an unseen knowledge. In this article, they are evaluated by citing the examples of dreams that have consequences especially in the field of practice. And also it was given information about the application and binding of dreams in terms of usul al fiqh. According to this, the general rule about acting on dreams is that any religious judgement cannot be constant by any dream except the prophets'. Besides, in (according to) an existing shariah ruling, it cannot be changed or canceled with dream. The person who has the dream can act only in permissible areas and with dreams that point to the aim of leading good and preventing evil. There is no obligation also for this issue, and if the person doesn't want to, he may not act with the dream he had, even in these areas.

Keywords: Fiqh, Usul al-Fiqh, Dream, Tasavvuf (Sufism), Dream Interpretatıon.

\section{Structured Abstract}

Dreams have always attracted people's attention due to their being mysterious and the possibilities of having signs of future life. Islamic scholars state that some of the dreams come out under the influence of daily lives or as an imaginary. They also considered some dreams as observing symbols of things that have happened or will happen in the future through a window that opens to the spiritual realm. Such dreams are given great importance, and since they were thought to carry signs in various ways, activities were carried out to interpret these dreams in order to clear up the messages in them.

The dreams of some prophets or historical figures were described in the Qur'an, and the interpretation of these dreams was mentioned. This case has been considered as being a sign of divine messages. It is a historical reality that the Prophet had interpreted the dreams of the Sahabah (Companions). Even, an important sign of the religion of Islam, such as the azan, firstly became definite upon having been dreamed. Such practices in the time of the Prophet show that dreams have had important characteristics.

Among the Islamic sciences, sufism is the branch that deals with dreams the most. Sufism refers to the spiritual life aspect of Islam. Dreams are of great importance in sufi life, especially at the stage of 'seyr ü süluk', which is the spiritual education process of new followers of sufism. Because this process is usually carried out according to the dreams. However, the usage of dreams in sufism is not limited. Sufis have benefited from dreams in many issues, like which city they will reside in, who they will choose as their followers, and who they will leave. In addition to this, it is seen that sufis have made judgments about fiqh/practical issues for some dreams they have seen. This is related to the fact that dreams are reliable information sources for the sufis. Because dreams have an important place in sufi epistemology.

Due to the fact that true dreams are considered as reliable sources of information by mystics, important functions have been attributed to dreams in many mystical practices. The importance of dreams in sufism has also been studied by some academicians. In this article, the reflection of the dreams of mystics in the practical/fiqh field is the subject of research. For, it is seen that dreams expressed by sufis not only convey some unseen information but It is seen that there are also results related to the field of fiqh. It is thought that the information put forward as a result of this research will contribute to studies in both sufism and fiqh.

The dreams that come to the fore in the dreams of sufis and are reflected in their lives can be grouped as follows: Some sufis were assigned duties by the 
Prophet or other leading sufis in their dreams. In some dreams, the sufis were warned that their behavior was wrong, and they were asked to be corrected. In some dreams, prayers and dhikrs were learned from Prophet Muhammad or pioneer sufis. In many of the dreams told by sufis, it was required to learn from the deceased people about death and what happened after death. We can mostly see such dreams have been narrated in sufism books.

Accordingly, dreams are sometimes used as a means of conveying a hadith from the Prophet. It is sometimes used to learn or correct a fiqh rule, and sometimes to obtain an unseen knowledge. In addition, it is observed that some evaluations are made by fiqh scholars regarding the reliability of dream-based information and whether they are effective in making judgments or not. According to scholars, the information obtained through dreams is not a reliable source of information because it is not based on any research and evidence, cannot be distinguished as right or wrong, and cannot be known for sure whether it is from Allah or an angel. Therefore, dreams are not considered valid in terms of fiqh.

As a result of the research, the following findings were made: The general rule about acting on dreams is that any religious judgement cannot be constant by any dream except the prophets'. Also, a religious judgement cannot be changed or canceled by means of dreams. The person who has the dream can act only in permissible areas and with dreams that point to the aim of leading good and preventing evil. There is no obligation also for this issue, and if the person doesn't want to, he may not act with the dream he had, even in these areas.

\section{Giriș}

Rüyalar gizemli oluşları ve özellikle gelecek hayata dair işaretler taşıma ihtimalleri nedeniyle her zaman için insanların ilgisini çekmiştir. Tarih boyunca herhangi bir dinî inanca sahip olsun veya olmasın insanların, rüyaların esrarına olan bu ilgisi devam etmiş olup günümüzde de devam etmektedir. Rüyaları açıklamak ve onlardaki sembolleri çözmek için dinî, felsefi ve bilimsel açıklamalar yapılmaya çalışılmıştır. Çağımızda özellikle batılı bilginlerin rüyalar üzerindeki çalışmalarında rüyaların, bilinçaltının veya geçmiş yaşantının birikiminin bir yansıması olarak görüldüğü dikkat çekmektedir. ${ }^{1}$ İslam bilginlerinin yaklaşımında ise rüyaların bir kısmının günlük yaşantıların etkisinde veya hayal ürünü olarak ortaya çıktığı değerlendirilirken, bir kısım rüyalar ise olmuş veya olacak şeylere dair sembollerin hakikat âlemine açılan bir pencereden müşahede edilmesi olarak görülmüştür. ${ }^{2} \mathrm{Bu}$

1 Batılı bilginlerin rüya hakkında görüşleri ve değerlendirmeleri için bk. Sigmund Freud, Düşlerin Yorumu, çev. Emre Kapkın (İstanbul: Payel Yayınevi, 1996), 61-93; Erich Fromm, Rüyalar Masallar Mitoslar (Sembol Dilinin Cözümlenmesi), çev. Aydın ArıtanKaan H. Ökten (İstanbul: Arıtan Yayınevi, 1992), 39-129; Abdülhakim el-Afîfî, Bilimsel ve Dinî Açıdan Rüyalar ve Kâbuslar, çev. Bünyamin Açıkalın (İstanbul: Rağbet Yayınları, 2011), 59-74; Abdulvahit İmamoğlu, "Bazı Psikanalistlere Göre Rüyanın İnsan Hayatındaki Rolü”, Sakarya Üniversitesi İlahiyat Fakültesi Dergisi 12/22 (2010/2), 22-46.

2 Zeynülislâm Abdülkerîm b. Hevâzin el-Kuşeyrî, Kuşeyrî Risâlesi. çev. Süleyman Uludağ (İstanbul: Dergah Yayınları, 2016), 467; Ebû Hâmid Muhammed b. Muhammed Gazzâlî, İhyâu 'ulûmi'd-dîn (Beyrut: Dâru İbn Hazm, 2005), 1889-1890; Fahreddîn Muhammed b.

Turkish Academic Research Review - Türk Akademik Araştırmalar Dergisi 
şekilde olan rüyalar oldukça önemli addedilmiş, bunların çeşitli şekillerde işaretler taşıdığı düşünüldüğünden bu rüyalardaki sembollerin ve mesajların çözülmesi yönünde yorumlama faaliyetlerinde bulunulmuştur. İnsanların zaman zaman yaşadıkları tecrübelerde, rüyalarda istikbalde meydana gelecek olaylara dair işaretlerin olduğunu müşahede etmeleri de rüyaya ve rüya yorumlarına ilginin sürekli olarak devam etmesine sebep olmuştur.

İslami ilimler içerisinde rüyalarla en çok ilgilenen bilim dalının tasavvuf olduğu görülmektedir. Rüyaların, özellikle tasavvuf ilminin ilgi alanına girmesi her ikisinin de sembolik dile sahip olmaları yönüyle açıklanmıştır. Çünkü sûfîlere göre rüyalar misal âleminde görülür, bu nedenle rüyaların dili semboliktir. Sembolik oluşları nedeniyle de tevile/tabire ihtiyaç duyarlar. Tasavvufun dilinin de sembolik olduğu düşünüldüğünde, rüya dili ile benzeşiyor olması tesâdüfî değildir. ${ }^{3}$ Yani rüyaların sembolik dile sahip oluşları nedeniyle doğal olarak tasavvuf alanının önemli bir konusu haline geldiği anlaşılmaktadır. Mutasavvıfların rüyalara olan bu ilgisi, onu tasavvuf epistemolojisinde önemli bir unsur haline getirmiştir. Sadık rüyaların sûfîlerce vahyin bir türü olarak görülüp güvenilir bilgi kaynağı sayılması ${ }^{4}$ nedeniyle, birçok tasavvufî uygulamada rüyalara önemli işlevler yüklenmiştir.

Tasavvufta rüyanın önemi bazı akademisyenlerce de ele alınarak incelenmiştir. $^{5} \mathrm{Bu}$ makalede ise sûfîlerin gördükleri rüyaların, amelî/fikhî alana yansıması araştırma konusu edilmiştir. Zira sûfîlerce dile getirilen rüyaların sadece bazı gaybî bilgileri aktarmakla kalmadığı, fikhî alanla ilgili sonuçlarının da olduğu görülmektedir. ${ }^{6}$ Rüyalar bazen Hz. Peygamberden bir söz aktarımında, bazen bir fikhî hükmün düzeltilmesinde ve bazen de bir gaybî bilginin elde edilmesinde

Ömer Râzî, Tefsîru'l-Kebîr (Mefâtîhu'l-Gayb) (Beyrut: Dâru'l-Fikr, 1981), 18/96; Abdurrahman b. Muhammed b. Haldun el-Hadramî, Mukaddime, çev. Halil Kendir (Ankara, y.y., 2004), 1/139-140. İslam âlimlerinin rüyanın mahiyetine dair açıklamalarına dair geniş bilgi için bk. Selim Özarslan, "İslami Kaynaklar Işı̆̆ında Rüya Konusuna Kelamî Bir Bakış", Diyanet İlmi Dergi 45/ 4 (2009), 90-93.

${ }^{3}$ Kadir Özköse, "Sûfî Gelenekte Rüya", Somuncu Baba Aylık İlim - Kültür Ve Edebiyat Dergisi 129 (Temmuz 2011), 26.

4 İsmail Hakk1 Bursevî, Tefsîru rûhi'l-beyân (İstanbul: Matbaat-ü Osmaniyye, 1330/h.), $4 / 458$.

5 Örnek olarak bk. Murat Kayacı, Tasavvuf Geleneğinde Rüya (Çorum: Hitit Üniversitesi Sosyal Bilimler Enstitüsü, Yüksek Lisans Tezi, 2018); Abdullah Demir, "Tasavvufta Rüya Tabiri”, USBD Uluslararasl Sosyal Bilimler Dergisi 1/9 (2017), 41-49; Bülent Akot, "Tasavvufî̀ Terbiyede Rüyânın Değeri”, Hitit Üniversitesi Illahiyat Fakültesi Dergisi 10/19 (2011/1), 93-113; Osman Nuri Küçük, "Muhyiddîn İbnü’l-Arabî’ye Göre Rüya ve Tabiri," Marife: Dini Araştırmalar Dergisi [Bilimsel Birikim] 14/3 (2014), 31-56; Zeliha "Öteleş, Tasavvufun Metafizik Omurgası: Rüya -Fusûs Merkezli Bir Değerlendirme-", Süleyman Demirel Üniversitesi İlahiyat Fakültesi Dergisi 43/2 (2019/2), 139-147; Selim Özarslan, Günümüz Kelam İnanç Problemleri (Ankara: Nobel Yayınları, 2016), 179-191; a.mlf., "İslami Kaynaklar Işı̆̆ında Rüya Konusuna Kelamî Bir Bakış", 89-108.

${ }^{6}$ Bursevî, Rûhu'l-beyân, 3/91; 4/461. 
kullanılmaktadır. ${ }^{7}$ Ayrıca rüyaya dayalı bilgilerin güvenilirliğine dair fikıh usulcülerince bazı değerlendirmelerin yapıldığı, hüküm istinbatında etkili olup olmadıklarının incelendiği müşahede edilmektedir. ${ }^{8}$ Tasavvuf ehlince kabul gören rüyaların burada belirtilen çerçevede örnekler üzerinde incelemeleri yapılmıştır. $\mathrm{Bu}$ araştırma sonucu ortaya konulan bilgilerin hem tasavvuf hem de fikıh alanındaki çalışmalara katkı sunacağı düşünülmektedir.

\section{Rüyaya Dair Genel Bilgiler}

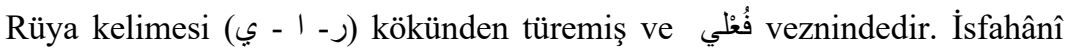
(502/1108?) rüyay1; " الرؤيا ما يري في المنام Rüya, uykuda görülen şeydir"9 şeklinde tanımlamıştır. Genel olarak uyku sırasında zihinde beliren görüntülerin bütününün rüya olarak isimlendirildiği görülmektedir. ${ }^{10}$

Rüyanın görülmesini sağlayan şeyler, geçmiş yaşantının iyi veya kötü tecrübeleri, gelecek hakkındaki düşünceler ve bunlar dışında bazı dış etkenlerdir. ${ }^{11}$ İslami literatürde rüya türleri, kaynağına bağlı olarak sâdık rüya, şeytânî rüya ve nefsânî rüya şeklinde üç tür olarak yaygınlık kazanmıştır. Bu sınıflamanın da Hz. Peygamberin bu konudaki bir hadisine dayandığı görülmektedir. Hz. Peygamber bu hadisinde; “لله الرويا ثلاث: حديث النفس وتخويف الثيطان وبشرى من Rüya üç türdür: Kişsinin nefsinden kaynaklanan, şeytanin korkutmast olan ve Allah'tan bir müjde olan rüya." ${ }^{12}$ Buna göre rüyalar, Allah'tan müjdeli mesaj içeren sâdık rüyalar; şeytanın vesvese ve korkutmalarından oluşan şeytanî rüyalar ve insanın günlük yaşamındaki durumlarından kaynaklanan nefsânî rüyalar olarak sınıflandırılmıştır. ${ }^{13}$ Sadık rüyanın, şer‘î esaslara aykırı olmamak, tekrarlamak, çok (sık) görülmek, rüyayı görenin aniden uyanması, rüyanın unutulmayıp bütün ayrıntıları ile görenin zihninde kalması ve kolay hatırlanması gibi özellikler taşıdığı belirtilmiştir. ${ }^{14}$

${ }^{7}$ Kuşeyrî, Kuşeyrî Risâlesi, 476; Ebu Bekir Muhyiddin Muhammed b. Ali İbnü'l-Arabî, elFütûhâtü'l-Mekkiyye (Beyrut: Dâru'l-Kütübi'l-İlmiyye, 1999), 2/89,8/387; Bursevî, Rûhu'lbeyân, $3 / 91$.

8 Ebû İshak İbrâhîm b. Mûsâ eş-Şâtıbî, el-Muvâfakât, çev. Mehmet Erdoğan (İstanbul: İz Yayıncilık, 1999), 2/272-273; Ebû Muhammed Alî b. Ahmed b. Saîd İbn Hazm, el-ìhkâm fî Usûli'l-Ahkâm, (Beyrut: Dâru'l-Âfâki'l-Cedîde, 1979), 7/98.

9 Ebü'l-Kâsım Hüseyn b. Muhammed er-Râgıb el-İsfahânî, el-Müfredât, thk. Muhammed Seyyid Keylanî (Beyrut: Dâru'l-Ma'rife, ts.), 209.

10 İlyas Çelebi, "Rüya", Türkiye Diyanet Vakfi İlam Ansiklopedisi (Ankara: TDV Yayınları, 2008), 35/306.

11 Cağfer Karadaş, "Rüyanın Mâhiyeti Bilgi ve Hüküm Değeri”, Diyanet İlmi Dergi 3/1 (2017), 45.

12 Buhârî, "Ta'bir", 26.

13 İbrahim Paçacı, "Rüyâ'nın Delil Değeri Ve İstihâre", Dini Araștırmalar 19/48 (OcakHaziran 2016), 109-110.

${ }^{14}$ Hasan Şerkâvî, Mu'cemu elfâzi's-sûfiyye (Kahire: Müessesetü'l-Muhtar, 1987), 155; Afîfî, Bilimsel ve Dinî Açıdan Rüyalar ve Kâbuslar, 77.

Turkish Academic Research Review - Türk Akademik Araştırmalar Dergisi 
İslâm âlimlerinin rüyaya bakışına örnek olarak burada sadece Gazzâlî’nin (505/1111) rüyanın oluşumuna dair açıklamasını aktaracă̆ız. O, sadık rüyayı aynaya benzettiği Levh-i Mahfûz'dan yansımalar olarak açıklamıştır. Buna göre Levh-i Mahfûz, olmuş olacak bütün şeylerin bilgisinin üzerine nakşedildiği bir ayna gibidir. Bu aynadaki suretler, yine bir ayna hükmündeki kalbe yansır. Ancak kalbin önünde perdeler doğrudan o bilgilere ulaşmayı engeller. Uyanık olan insan mülk ve şehadet âlemi ile meşgul olduğundan bu onun önünde bir perdedir. ${ }^{15}$ Uyku ise duygu ve düşüncelerin kalbi meşgul etmediği bir durum olduğundan, insanın bu sâfiyet halinde Levh-i mahfuz aynasından kalp aynasına yansımalar olur. Levh-i Mahfûz'dan gelen bu yansımaları hayal kuvveti alır ve benzer bir misal ile hikâye eder. İnsan bu gördükleri şeyleri uyanınca rüya olarak hatırlar. ${ }^{16}$ Mutasavvıf müfessirlerden Bursevî (1137/1725) de Allah'ın vazifelendirdiği bir meleğin, Levh-i Mahfuz'dan bilgiler alarak gelecekte gerçekleşecek her olay için bir misal getirdiğini ve bunu uykusunda insana hikmet yolu üzere temsilî olarak gösterdiğini belirtir. Buna göre rüya, görülen suretlerin resmedilmesi ve kalp aynasında nakşedilmesidir. Bu rüya insan için müjde, ikaz veya itâp olabilir. Ayrıca ona göre rüya bir ilim babındandır. ${ }^{17}$

Kur'an'da, bazı peygamberlerin veya tarihi şahsiyetlerin rüyalarının anlatılmış olması, bu rüyaların tabirine ve bunların gerçekleştiğine yer verilmesi, rüyaların bir kısmının ilahi mesaj taşıdığının göstergesidir. Hz. Peygamberin sahabeden rüya görenlerin rüyalarını tabir etmesi, hatta ezan gibi önemli bir dini şiârın ilk olarak rüyada görülmeye dayalı olarak sabit olması da rüyalara önemli hususiyetler yüklendiğini göstermektedir. Ayrıca Hz. Peygamberin, "Doğru rüyâ (sadık rüya) Allah'tan, hulm ise şeytandandır."18, "Mü'minin rüyası, nübüvvetin kırk altı cüzünden bir cüzdür." ${ }^{19}$ hadisleri rüyalara verilen değeri göstermesi bakımından önemlidir. Ayrıca Hz. Peygamberin, mübeşşirâttan başka nübüvvetten bir şey

15 İnsanın kalbini perdeleyen ve onu müşahededen alıkoyan şeyler ise kısaca şöyle belirtilebilir: Günahlarda israr etmek, nefsin ve şehvetin istekleri peşinde koşmak suretiyle gaflet içerisinde bulunmak, büyüklenmek, riyakârlık, kıskançlık, öfke, kin, yalan söylemek gibi kötü ahlaki hasletlere sahip olmak, dünyalık mal ve makam sevgisi taşımak, haram lokma yemek, zahir ve bâtın temizliğe dikkat etmemek. Gazâlî’ye göre kalbin tasfiyesine mani olan sebepler hakkında geniş bilgi için bk. Mevlüt Özçelik, İmam Gazâlı̂’ye Göre Nefsin Tezkiyesi ve Kalbin Tasfiyesi (Ankara: Sonçağ Akademi, 2020), 227-232.

16 Ebû Hâmid Muhammed b. Muhammed el-Gazzâlî, Ihyyâu u'lûmi'd-dîn (Beyrut: Dâru İbn Hazm, 2005), 1889-1890.

${ }^{17}$ Bursevî, Rûhu'l-beyân, 4/213-214.

18 Ebû Abdillah Muhammed b. İsmail b. İbrahim el-Buhârî, Sahihi Buhârî (Dimeşk-Beyrut: Dâru İbni Kesîr, 2002), "Ta'bir", 3.

19 Buhâri, "Ta'bir", 4. Bu hadisin değişik riyayetleri de vardır: "Salih bir kişi tarafindan görülen güzel rüya, peygamberliğin kırk altı cüzünden bir cüzüdür." (Buhârî, "Ta'bir”, 2), "Sâlih rüyâ, nübüvvetin kırk altı cüzünden bir cüzdür." Buhâri, "Ta'bir", 4. 
kalmadığını belirtmesi ve mübeşşrâtın ne olduğu sorusuna da 'salih rüyalardır'20 şeklinde cevap vermesi de rüyanın önemine bir vurgu olarak değerlendirilmiş̧ir. ${ }^{21}$ $\mathrm{Bu}$ rivayetler, rüyaların $\mathrm{Hz}$. Peygamber döneminde dini hayatın şekillenmesi üzerinde etkisinin bulunduğunu; Hz. Peygamberin de rüyalara ve tabirine önem verdiğini göstermektedir. Bu konuda şu değerlendirme de yapılmıştır: Kur'an'da ve önceki kutsal kitaplarda peygamberlerin rüyalarına yer verilmesi ve bu rüyaların hayata yansımalarının olduğunun görülmesi, insanların rüyalara bu denli önem vermelerinde etkili olmuştur. Eğer bu şekildeki peygamber rüyaları olmasa idi insanlar rüyalarla bu derece ilgilenmeyecek, gördükleri rüyaları yorumlamak ve araştırmak için bu kadar çaba sarfetmeyeceklerdi. ${ }^{22}$

İçerisinde Hz. Peygamberin görüldüğ̈̈ rüyalar; "من رآني في المنام فقد رآني Beni rüyada gören, gerçekten beni görmüştür." ${ }^{23}$ hadisi nedeniyle en sadık rüyalar olarak görülmüştür. Buna göre Hz. Peygamberi aslî sureti üzere rüyasında gören kişinin ve peygamberin ona söylediklerini bildiren kişinin verdiği bilgilerde hiçbir eksiklik ve değişiklik olmayacağı, bilakis bunların açık bir nas şeklinde görülmüş olduğu ve ondan rivayet edilebileceği özellikle sûfilerce dile getirilmiştir. ${ }^{24} \mathrm{~Hz}$. Peygamberi görenin onu gerçekten görmüş olacağı rivayetinde kastedilenin sahabeler olduğu, yani Hz. Peygamberi gerçek hayatta gören, onu bizzat tanıyan ve şemâilini bilen kişilerin gördükleri rüyada onu gördüklerini kesin olarak bilebilecekleri, onların dışında hayatta iken peygamberi görmeyenlerin rüyalarında gördükleri kişinin peygamber olduğunu bilemeyecekleri de dile getirilmiştir. Buna göre sahabe dışında peygamberi rüyasında gördüğünü söyleyenler, sadece kendilerinde bu yönde oluşan bir kanaate dayalı olarak bunu söylemektedirler. Bu duruma göre bu rüyaların diğer rüyalardan farkı olmayıp sıradan bir rüya hükmünde olduğu dile getirilmiştir. ${ }^{25}$

\section{Tasavvufta Rüya ve Önemi}

Tasavvuf anlayışında rüya, ilham ve keşf gibi manevi bilgi kaynaklarından sayılmıştır. ${ }^{26} \mathrm{Bu}$ nedenledir ki tasavvufun önde gelen isimlerinin hayatlarını şekillendirmelerinde rüyaların büyük etkisi olduğu görülmektedir. Tasavvuf yoluna girmek isteyen bir kişinin hangi mürşide bağlanacağından, bir mürşid-i kâmilin

${ }^{20}$ Buhârî, "Ta'bir", 5.

${ }^{21}$ Bursevî, Rûhu'l-beyân, 4/61.

${ }^{22}$ Afîfî, Bilimsel ve Dinî Açıdan Rüyalar ve Kâbuslar, 127.

${ }^{23}$ Buhârî, "Ta'bîr", 10.

24 Mehmet Eren, "Sadreddin Konevî’nin Tasavvufî Hadis Şerhçiliği Hz. Peygamber'in Rüyada Görülmesi Rivayeti Çerçevesinde", I. Uluslararası Sadreddin Konevî Sempozyumu Bildirileri (Konya: Mebkam, 2008), 111.

25 Eren, "Sadreddin Konevî’nin Tasavvufî Hadis Şerhçiliği Hz. Peygamber'in Rüyada Görülmesi Rivayeti Çerçevesinde", 107-110

${ }^{26}$ Gazzâlî, İhyâü 'ulûmi'd-dîn, 1893; Bursevî, Rûhu'l-beyân, 4/458.

Turkish Academic Research Review - Türk Akademik Araştırmalar Dergisi 
nerede irşat faaliyeti yürüteceğine kadar birçok hususta kendilerine rüyalarında işaret edilen bilgiye göre hareket ettikleri görülmektedir. Örneğin Aziz Mahmut Hüdâyî (1038/1628), Bursa'da kadılık ve müderrislik görevinde iken, gördüğü bir rüya üzerine bu vazifeleri terk ederek ve elinde bulunan tüm malını fakirlere tasadduk ederek Üftâde Mehmed Muhyiddin'e (988/1580) intisap etmiştir. ${ }^{27}$ Sûfîlerin rüyaya verdikleri önemin sebeplerinden birini Kuşeyrî şöyle açıklamaktadır: Uykuda bazı mana ve meziyetler vardır ki, bunlar uyanıkken gerçekleşmez. Bunlardan birisi Hz. Muhammed'i, sahabeyi ve önceki âlimleri rüyada görmektir. Bunlar uyanıkken görülmezler. Hak Teâlâ’nın rüyada görülmesi de böyledir. Bu büyük bir meziyettir. ${ }^{28}$

Tasavvufta rüyanın en çok kullanıldığı alan 'seyr ü sülûk'tur. Seyr ü sülûk, tasavvufa giren kişinin (sâlikin) manevî makamları tamamlayıncaya kadar geçirdiği safhaları, diğer bir deyişle sâlikin nefsini terbiye etmek ve Hakk'a ulaşmak için yaptığı yolculuğu ifade eder. ${ }^{29}$ İşte bu manevi eğitim yolculuğunda sâlikin durumu gördüğü rüyalar yorumlanarak şeyhi tarafindan tespit edilir ve bunlara göre eğitim şekli yapılandırılır. Zira rüyalar insanın iç dünyasına ışık tutar, ortaya çıkmasını sağlar. Bu nedenle rüya yorumu tasavvuftaki manevi eğitimde önemli bir işleve sahiptir. ${ }^{30}$ Sonuçta tarikatlarda müridin manevi yükselişinin takibinin gördüğü rüyalar sayesinde yapıldığı ortaya çıkmaktadır. Bu nedenle de genel olarak tarikatlarda rüyaya büyük önem verilmiştir. Bu durumun özellikle esmâ zikriyle seyr ü sülûk usulünü uygulayan tarikatlarda öne çıktığı da belirtilmelidir. Tasavvufta genel olarak önemli işlevlere sahip olan rüyaya, Nakşibendîler ile Melâmîlerin ise çok önem vermedikleri belirtilmiştir. ${ }^{31}$ Örneğin Nakşibendî tarikatının önemli isimlerinden İmam Rabbânî (1034/1624) rüyaların, şeytanın hile ve tuzaklarından korunmasının çok zor olacağını, zira uyku halinin insanın idrak ve duygularının boşa

27 H. Kamil Yılmaz, Aziz Mahmut Hüdâŷ̂ (Ankara: Diyanet İşleri Başkanlığı Yayınları, 2016), 13; Turgut Koçoğlu, İki Kutup Hüdâŷ̂ Ve Üftâde Bir Eser Vâkı'ât Tercümesi, (Kayseri: Laçin Yayınları, 2014), 23.

${ }^{28}$ Kuşeyrî, Kuşeyrî Risâlesi, 469.

29 Süleyman Uludağ, "Sefer", Türkiye Diyanet Vakfi İslam Ansiklopedisi (İstanbul: TDV Yayınlar1, 2009), 36/298; H. Kamil Y1lmaz, Ana Hatlartyla Tasavvuf ve Tarikatlar (İstanbul: Ensar Neşriyat, 2015), 183.

30 Süleyman Uludağ, "Rüya", Türkiye Diyanet Vakfi İslam Ansiklopedisi (Ankara: TDV Yayınlar1, 2008), 35/309-310; Demir, "Tasavvufta Rüya Tabiri”, 41-49.

${ }^{31}$ Yılmaz, Ana Hatlartyla Tasavvuf ve Tarikatlar, 318; a. mlf. "Konevî’de Rüyâ Anlayıșı", I. Uluslararası Sadreddin Konevî Sempozyumu Bildirileri (Konya: Mebkam, 2008), 247; Bülent Akot, "Tasavvufî Terbiyede Rüyânın Değeri”, Hitit Üniversitesi Illahiyat Fakültesi Dergisi 10/19 (2011/1), 111. 
çıktığı, yanılma ve şüpheye açık bir mahal olduğunu belirterek, rüyaların güvenilir bir dayanak olamayacağını dile getirmektedir. ${ }^{32}$

Rüyalar, sâlikin sülûkunda bu derece önemli olduğundan, sâliklerin gördükleri rüyaları şeyhi tabir etsin ya da tabire değer görmesin yine de mutlaka şeyhine anlatması gerektiği belirtilmiştir. Buna göre gördüğü rüyayı şeyhine anlatmak müridin, anlatılan rüyayı yorumlamak da mürşidin mutlaka yapmaları gereken görevleri olmaktadır. ${ }^{33}$

Sûfilerin hayat hikayeleri incelendiğinde gördükleri rüyaların hayatlarına etkisinin gayet fazla olduğu görülecektir. Hatta rüyada Hz. Peygamberden hadis nakline dair bilgiler dahi tasavvuf kaynaklarında yer bulabilmektedir. Örneğin, Ebû Abdullah b. Hafif' in rüyasında Hz. Peygamberi gördüğü ve onun kendisine şöyle dediği nakledilmiştir: "Kim Allah'a giden bir yolu ögrenir, sonra bu yolu tutar ve daha sonra da bu yoldan dönerse Allah, bu kişiyi âlemde hiç kimseye vermediği bir azap ile cezalandırır." 34 Görüleceği üzere bu durum, rüya yolu ile doğrudan $\mathrm{Hz}$. Peygamberden rivayette bulunma şeklidir. Tasavvufa dair eserlerde rüyalara dair oldukça bol miktarda aktarımlara rastlanmaktadır. Ancak burada sûfîlerin gördükleri genel konulara dair rüyalar üzerinde durulmayacaktır. Sadece amelî/fıkhî alana yansıması olan rüyalardan bazı örnekler aktarılacak ve bunlar üzerinden değerlendirmede bulunulacaktır.

Sûfîlerin rüyalarında öne çıkan ve hayatlarına yansıması olan rüyalar şu şekilde gruplandırılabilir: Bazı sûfîlere rüyalarında, Hz. Peygamber veya diğer önde gelen sûfilerce bazı görevler tevdî edilmiştir. Bazı rüyalarda sûfînin yapmakta olduğu bir davranışın hatalı olduğu yönünde uyarılar yapılmış, düzeltilmesi istenmiştir. Bir kısım rüyalarda Hz. Peygamber veya tasavvuf büyüklerinden dua ve zikirler öğrenilmiştir. Sûfîlerce anlatılan rüyaların birçoğunda ise vefat etmiş kimselerden ölüm ve sonrasında yaşananlara dair bilgiler öğrenilmek istenmiştir. Tasavvuf kitaplarında en çok bu yönde rüyaların anlatıldığı görülmektedir. Ayrıca bazı rüyalarda da Hz. Peygamberden haber yahut fetva aktarıldığı görülmektedir. Bu sınıflamaya göre, aşağıda bazı örnek rüyalar aktarılacaktır.

Sûfîlerin Hz. Peygamberi rüyada görerek onun tarafından çeşitli görevlere vazifeli kılındıklarına dair örnek olarak; halka vaaz ve irşatta bulunması istendiği halde bundan kaçınan Cüneyd-i Bağdâdî’ye (297/909), Hz. Peygamberin rüyasında

\footnotetext{
32 Ahmed el-Fârûkî es-Serhendî (İmam Rabbânî), Mektûbât. çev. Abdülkadir Akçiçek (İstanbul: Dergah Ofset, 1998) 2/158.

${ }^{33}$ Bursevî, Rûhu'l-beyân, 9/405.

${ }^{34}$ Kuşeyrî, Kuşeyrî Risâlesi, 476; Bursevî, Rûhu'l-beyân, 1/353.
}

Turkish Academic Research Review - Türk Akademik Araştırmalar Dergisi 
halka vaazda bulunmasını emretmesi ve bunun üzerine onun da halka vaaz ve nasihatta bulunmaya başlaması verilebilir. ${ }^{35}$

Hz. Peygamberin, sûfîleri rüyalarında bazı tasavvufî meselelerde dikkatli olmaları konusunda uyarmasına dair şu örnekler zikredilebilir: Hz. Peygamber, kendisini rüyasında gören bir sûfîyi, en çok semâ konusunda hata yapıldığı/günaha düşüldüğü şeklinde uyarmıştır. ${ }^{36}$ Bir diğer örnek ise rüyasında kendisinin bir şiir okuduğu yahut kasîde terennüm ettiğini gören sûfiye, Hz. Peygamberin yaklaşıp onun göğsüne vurarak "bunlar hayırdan çok şerri olan şeylerdir" demesidir. ${ }^{37} \mathrm{Bu}$ konuda bir diğer örnek de Üftâde Mehmed Muhyiddin'den verilebilir. O, sesinin güzelliği nedeniyle insanların 1srarı sonucu Bursa Ulu Camii'nde ve Doğan Bey Mescidi’nde bir miktar ücret karşılığı müezzinlik yapmayı kabul etmiş, kendisine bağlanan ilk maaşı aldığında ise rüyasında "mertebenden üftâde oldun" şeklinde itâba uğraması üzerine derhal bu görevi bırakmış ve kendisi için bu "Üftâde" mahlasını kullanmaya başlamıştır. ${ }^{38}$

Sûfîlerin bazı rüyalarında $\mathrm{Hz}$. Peygamberden veya vefat etmiş tasavvuf büyüklerinden dua talep ettikleri, onların da bazı dua ve zikirleri onlara öğrettiğine dair örnek olarak; kalbinin ölmemesi için dua isteyen bir sûfîye rüyasında $\mathrm{Hz}$. Peygamberin, "her gün kırk defa Yâ Hayy, Yâ Kayyûm, Lâilâhe illâ ente" demesi halinde Allah'ın kalbini ihya edeceğini söylemesi örnek olarak verilebilir. ${ }^{39}$

Sûfîlerin rüyalarda en çok dile getirdikleri şeylerin ise vefat etmiş olan insanları rüyada görüp, onlara ölümünden sonra karşılaştıkları şeylere dair sorular sormaları ve onlardan bilgi almaya çalışmalarıdır. Bu tür rüyaların bir kısmında Allah'ın kendilerine merhameti ile muamele ettiğine dair bilgiler aktarılır. Bu bilgilerde genelde kurtuluşa vesile olan şeyler hakkında, gece namazı, bazı zikirler, Kur'an okuma ve okutma, infakta bulunma vb. davranışlar nedeniyle Allah'ın kendilerine merhameti ile muamelede bulunduğu, af ve ikrama mazhar olduklarını bildirmişlerdir. ${ }^{40}$ Ancak rüyaların bir kısmında ise dünyadaki savundukları görüşler konusunda onlara sorular sorulmuş, onlar da eski görüşlerinde sabit oldukları veya bu fikirlerinden vazgeçtikleri yönünde açıklamalar yapmışlardır. Örneğin İzzüddin b. Abdüsselam'ın (660/1262) hayattayken; “Insana çalışmasından başka bir şey

${ }^{35}$ Kuşeyrî, Kuşeyrî Risâlesi, 330.

${ }^{36}$ Kuşeyrî, Kuşeyrî Risâlesi, 432.

${ }^{37}$ Gazzâlî, İhyâü u 'lûmi'd-dîn, 1893-1895.

38 Nihat Azamat, "Üftâde", Türkiye Diyanet Vakfi İslam Ansiklopedisi. (İstanbul: TDV Yayınları, 2012), 42/282; Koçoğlu, İki Kutup Hüdâŷ̂ Ve Üftâde Bir Eser Vâkl'ât Tercümesi, 13.

${ }^{39}$ Kuşeyrî, Kuşeyrî Risâlesi, 470.

40 Kuşeyrî, Kuşeyrî Risâlesi, 470-477; Gazzâlî, İhyâu 'ulûmi'd-dîn, 1893-1895; Bursevî, Rûhu'l-beyân, 10/316. 
yoktur."41 ayetini delil göstererek, ölen bir insan için arkasından okunan Kur'an'ın bir faydası olmayacağı görüşünü savunduğu, ancak vefat ettikten sonra onu rüyasında gören bir arkadaşının bu konuyu kendisine sorduğunda, dünyada iken bu düşüncede olduğunu, ancak ölümünden sonra gördükleri karşısında bu görüşünden döndüğünü, zira okunan ve sevabı bağışlanan Kur'an'ın vefat etmiş kişiye ulaşmasının hak olduğunu orada müşahede ettiğini belirtmiştir. ${ }^{42}$

Rüyada çözüme kavuşturulan fikhî bir meseleye dair Ebû Talip el-Mekkî (386/996), Kûtü'l-Kulûb adlı kitabında şöyle bir örnek zikretmektedir: Namazda tahiyyat okunurken bazı rivayetlerde sahabenin Hz. Peygamber hayatta iken “Esselamü aleyke eyyühen nebiyyü” şeklinde okurken, Hz. Peygamberin vefatından sonra ise, "Esselamü ale'n-nebiyyi” şeklinde okudukları nakledilmişs3 ve bu konuda ulemâ arasında tartışma yaşanmıştır. Sonuçta bazı sâlih kimseler Hz. Peygamberi rüyada görmüşler, ona ulemânın teşehhüd konusunda bu şekilde ihtilafa düştügünnü ve bunlardan hangi görüşün alınması gerektiğini sormuşlardır. Hz. Peygamber ise, İbn Ümmü Abd'in (Abdullah İbn Mes'ûd'un) bildirdiği şekilde olacağını söylemiştir. ${ }^{44}$ Aslında böylesi bir ihtilafın, fıkıh usulü ve hadis ilminin kuralları çerçevesinde değerlendirilip çözüme kavuşturulması gerekirdi. Zaten âlimler de bu şekilde değerlendirip tercihlerini Abdullah İbn Mes'ûd'un rivayeti yani, “Esselamü aleyke eyyühen nebiyyü" şeklinde okunması yönünde belirtmişlerdir. ${ }^{45}$ Ancak görüldüğü üzere burada mesele doğrudan rüyada Peygambere sorulmak suretiyle çözüme kavuşturulmuştur.

F1khî meseleleri rüyada Hz. Peygambere arz ederek doğrusunu öğrenme konusunda en çok örneğin Muhyiddin İbnü'l-Arabî (638/1240) tarafindan dile getirildiği görülmektedir. Ondan bu konuda birkaç örnek aktarmak istiyoruz: "Boşanmış kadınlar üç kuru' beklerler"46 ayetindeki boşanmış kadınların bekleme süresi olan ' $\ddot{u c ̧ ~ k u r u ' u n ~ n e ~ o l d u g ̆ u ~ f u k a h a ~ a r a s ı n d a ~ t a r t ı s ̧ m a l ı d ı r . ~}{ }^{47} \mathrm{Bu}$ konuda İbnü'lArabî, Hz. Peygamberi rüyasında gördüğünü, bu ayette geçen kuru' kelimesinin Araplarda zit anlamlı kelimelerden olduğunu, bu nedenle hem 'hayız' hem de

\footnotetext{
${ }^{41} \mathrm{Necm} 53 / 39$.

42 Bursevî, Rûhu'l-Beyân, 9/250; 10/305. Bu konuda geniş bilgi ve değerlendirmeler için bk. Derviș Dokgöz, Bursevî'nin Rûhu'l-Beyân Tefsirindeki Usûlî ve Fıkhî Görüşleri (Malatya: İnönü Üniversitesi Sosyal Bilimler Enstitüsü, Doktora Tezi, 2020), 178-180.

${ }^{43}$ Ahmed b. Hüseyn el-Beyhakî, es-Sünenü'l-kübrâ (Beyrut: Dâru'l-Kütübi'l-İlmiyye, 2003), 2/198-199.

${ }^{44}$ Ebu Talip el-Mekkî, Kûtü 'l-kulûb (Kahire: Mektebetü Dâru't-Türas, 2001), 3/1539.

45 Ebû Ca'fer Ahmed b. Muhammed b. Selâme et-Tahâvî, Şerhu müş̧kilü'l-âsâr (Beyrut: Müessesetü'r-Risâle, 1994), 9/409-410.

46 el-Bakara 2/228.

$47 \mathrm{Bu}$ konuda tartışmalar ve değerlendirmeler için bk. Muhammed Ali es-Sabûnî, Ravâiu'lbeyân tefsîru âyâti'l-ahkâm (Beyrut: Müessesetü Menâhilü'l-İrfan, 1980) 1/327-332.
}

Turkish Academic Research Review - Türk Akademik Araştırmalar Dergisi 
'temizlik' anlamına geldiğini, ayette bu kelime ile Allah'ın kastettiği mananın ne olduğunu kendisine söylemesini istediğini belirtir. Hz. Peygamberin ise onun sorusuna; 'kar'ı tamam olunca onun (kadının) üzerine suyu dökün ve Allah'ın sizi rızıklandırdığından yiyin’ şeklinde kinayeli cevap verdiğini, kendisinin de bundan kuru' kelimesinin anlamının 'hayız' olduğunu anladığını belirtmektedir. ${ }^{48}$

İbnü'l-Arabî'nin Hz. Peygamber'e rüyada sorup öğrendiğini belirttiği bir diğer fikhî mesele ise namazlarda rükûya giderken ve rükûdan kalkarken ellerin kaldırılıp kaldırılmayacağına dair tartışmadır. Bu konunun fukaha arasında tartışmalı olduğunu, kendisinin ise rüyasında Hz. Peygamberi gördüğünü, onun kendisine 'başlama tekbirinde, rükûya giderken ve rükûdan kalkarken ellerini kaldırmasını emrettiğini' dile getirmektedir. ${ }^{49}$ İbnü'l-Arabî'nin bu konuda bir diğer örneği ise şöyledir: Kendisinin önceden cenaze namazının hem cami içinde hem de cami dışında kılınabileceğini söylediğini, ancak daha sonra Hz. Peygamberi rüyasında gördüğünü ve onun cenazeleri camiye sokmaktan ve orada üzerine cenaze namazı kılmaktan nehyettiğini, kendisinin de bundan sonra cami içinde cenaze namazı kılmadığını belirtmektedir. ${ }^{50}$

Buna benzer bir örnek olmak üzere, Hz. Peygamberin rüyada görüldüğü ve Hz. Peygamberin, kusmaktan dolayı abdestin bozulması için kusmanın ağız dolusu olması gerektiğini söylediği de dile getirilmiştir. ${ }^{51}$

Sûfî müfessirlerden Bursevî ise uyku ile uyanıklık arasında (yakaza halinde) iken İbnü'l-Arabî ile görüştüğünü ve onun, halk arasında yaprak (tütün) denen şeyin haram olduğunu kendisine söylediğini aktarmaktadır. ${ }^{52}$

$\mathrm{Bu}$ son örneklerde görüldüğü üzere rüya yoluyla Hz. Peygamberin veya büyük mutasavvıfların açıklamalarından fıkhî konularda hükümler çıkarılmakta veya ihtilaflı fikhî meseleler rüyada Hz. Peygambere sorularak çözümlenmektedir. Belirtilen meselelerde elde edilen sonuçlar fikıh usulü ilminde mevcut olan hükümlere uygun olması halinde bile, bu bilgilerin bu şekilde rüyaya dayalı olarak elde edildiğinin söylenmesi sakıncalıdır. Zira insanın şuurunun/bilincinin kapalı olduğu uyku halinde gerçekleşen ve doğruluğu ya da yanlışlığı bilinemeyen ve

48 İbnü'l-Arabî, el-Fütûhâtü'l-Mekkiyye, 8/387.

49 İbnü'l-Arabî, el-Fütûhâtü'l-Mekkiyye, 2/89.

50 İbnü'l-Arabî, el-Fütûhâtü'l-Mekkiyye, 2/234. Muhyiddin Arabî'nin rüya ile $\mathrm{Hz}$. Peygamberden rivayette bulunması konusunda geniş bilgi için bk. Mehmet Ayhan, "Bir Rivayet Yöntemi Olarak Fütûhât-1 Mekkiyye'de Rüya İle Hadis Rivayeti”, Marife: Dini Arastırmalar Dergisi (Bilimsel Birikim) 11/2 (2011), 49-76.

${ }^{51}$ Bursevî, Rûhu'l-beyân, 3/91; 4/56

52 İsmail Hakkı Bursevî, Silsilenâme-i Celvetiyye, çev. Rahmi Serin, haz. Arif Pamuk (İstanbul: Pamuk Yayınları, ts.), 176. 
kontrol edilemeyen rüyalar yoluyla şer‘̂̂ hükümler elde edilebileceği kabul edilirse, bu durum dini hükümlerin ifsadına ve güvenilmez kaynaklara dayandırılmasına sebep olur ki bu doğru bir yaklaşım değildir.

\section{Fıkıh Usulü Açısından Rüyanın Amel Değeri}

F1kıh usulü açısından değerlendirildiğinde peygamber rüyalarının, güvenilir vahiy kapsamında olduğu, yani ya melek tarafindan bir ilkâ ya da Allah'ın onların kalbine doğrudan bildirmesi (vahyetmesi) şeklinde olduğu dile getirilmiştir. Nübüvvetin başlangıcında vahyin ağırlıklı olarak sâdık rüya şeklinde gelmesi de bunun bir göstergesi durumundadır. Ayrıca sonraki vahiy iniş sürecinde de birçok vahyin Hz. Peygamber uykuda iken vuku bulduğu bilinmektedir. Hz. İbrahim'e oğlunu kurban etmesi konusundaki emir de rüyaya dayalı gerçekleşen bir durumdur.

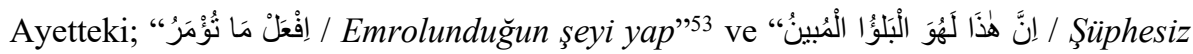
bu apaçık bir imtihandır" ifadeleri bunun İbrahim'e bir emir olduğunun delilleridir. Ayrıca Hz. İbrahim'in bir hayal/yalancı rüya ile oğlunu kurban etmeye kalkışması da düşünülemez. ${ }^{54}$

Şâtıbî (790/1388), ilham, keşf ve sadık rüya gibi bilgi kaynaklarına bağlı olarak Hz. Peygamberin çeşitli uygulamaları bulunduğunu, buna karşın bu özelliklere sahip (bu tür yetilere sahip) başka kimselerin de genel bilgi kaynakları dışındaki bu sübjektif kaynaklara dayalı olarak benzer uygulamalarda bulunabileceğini, ancak bunun şer`î bir esasa aykırı düşmemek kaydıyla mümkün olabileceğini belirtmektedir. Zira şer‘î bir hükme aykırılık teşkil eden şey, hak/doğru olarak görülemez. Bu özelliği taşıyan şey ne olursa olsun dikkate alınamaz. Çünkü Hz. Peygamberin getirdiği şeriatın esaslarına aykırılık taşıyan her şey batıldır. ${ }^{55} \mathrm{Bu}$ konuda örnek olarak İbn Rüşd'e (595/1198), bir davada şahitlik eden adalet sahibi iki kişi hakkında, dava hâkiminin rüyasında $\mathrm{Hz}$. Peygamberin kendisine 'bunların şahitliği ile karar vermemesini, bu şahitliğin geçersiz olduğunu' söylediği, bu durumda ne yapılacağının sorulduğunu aktarır. Böyle bir rüyaya, ne emir ne nehiy ne de müjdeleme ya da korkutma konusunda itibar edilemeyeceğini, çünkü açıkça şer‘î kaidelerden bir kaideye aykırılık teşkil ettiğini belirtir. Eğer uykuda görülen rüya veya keşf ile bu tür uygulamalara gitmek caiz olsa idi, zahirî gerekçelerin gereği olan hükümlerin bunlarla bozulması gerekirdi ki bu kesinlikle doğru değildir.

53 es-Sâffât 37/102.

${ }^{54}$ Ebü'l-Vefâ Alî b. Akīl b. Muhammed el-Bağdâdî, el-Vâzılh fì usûli 'l-fikh, thk. Abdullah b. Abdülmüslim et-Türkî (Beyrut: Müessesetü'r-Risâle, 1999), 4/306-309; Ebü'l-Hasen Seyfüddîn Ali b. Muhammed Âmidî, el-İhkâm fì usûli'l-fikh (Riyad: Dâru's-Samiî, 2003), 3/158-159.

55 Şâtıbî, Muvâfakât, 2/264-267.

Turkish Academic Research Review - Türk Akademik Araştırmalar Dergisi 
Kaldı ki Hz. Peygamber; "Ben ancak bir insanım. Siz bana bazı davalarla geliyorsunuz. Belki biriniz hüccetini diğerinden daha güzel ifade eder ve ben de ondan duyduğuma göre hüküm veririm...." ${ }_{56}$ buyurmak suretiyle davaları zahiri delillere göre karara bağladığını açıkça beyan etmiştir. ${ }^{57} \mathrm{~Hz}$. Peygamber vahiyle desteklendiği ve iç yüzlerini bildiği halde münafıklara karşı yine zahire göre davranışta bulunmuş, onların gerçekte ne olduklarını ve ne niyetle hareket ettiklerini bildiği halde onlara karşı uygulamalarında zahiri durumdan ayrılmamıştır. Şayet böyle gaybî bilgiye dayalı hareket etme kapısı açılırsa zahire göre hüküm verme esası tamamen ortadan kalkacaktır. ${ }^{58}$

Ancak bu konuda şer‘î bir kaideye aykırılık teşkil etmeyen bu tür bilgilerle tercihe bağlı olarak hareket edilmesi halinde bunlarda bir olumsuzluk görülmemiştir. Örneğin insanı iyiye yöneltme ve kötülükten sakındırma yönüyle bu tür şeylerle amel edilebileceğine dair örnek olarak da Abdullah İbn Ömer ile ilgili şu rivayet aktarılmaktadır: İbn Ömer'e rüyasında iki melek gelir ve onu cehenneme doğru sürüklerler. $\mathrm{O}$ ise iki meleğin arasında cehenneme götürülürken, 'Allah'ım cehennemden sana sığınırım' şeklinde dua eder. Bu sırada gelen üçüncü melek, 'Korkma! Sen ne iyi adamsın. (Ancak) Namaz kılmayı biraz çoğaltsan.' der. İbn Ömer, bu rüyasını uyandıktan sonra kız kardeşi Hafsa’ya anlatmış, o da Peygamberimize anlatmıştı. Bunun üzerine Peygamberimiz, "Abdullah ne iyi adamdır, keşke gecenin bir kısmında kalkıp namaz kılmayı da âdet edinseydi." demiştir. Abdullah İbn Ömer de bu rüyadan sonra fazla miktarda gece namazı kılmayı hiç terk etmemiş, gecenin az bir kısmı müstesna olmak üzere uyumayıp gece namazı kılmıştır. ${ }^{59} \mathrm{Bu}$ ve benzeri durumların, insanları uyarma ve müjdeleme türünde faydalı sonuçlar verdiği belirtilmiştir. ${ }^{60}$

Bir kişinin, mükâşefe veya rüya yoluyla başka birisinin iyi ya da kötü niyetle kendisine geleceğine vakıf olabileceği de belirtilmiştir. $\mathrm{Bu}$ durumda kendisine geliş amacının kötü olduğunu keşf veya rüya ile öğrenmiş ise buna göre önlemler alabilir. Ancak aldığı bu önlemler yine meşru sınırlar içerisinde olmalıdır. ${ }^{61}$ Yani keşfine veya rüyasına bağlı olarak elde ettiği bilgiye göre onu doğrudan suçlu ilan edemez, bunlara binaen cezalandırma yoluna gidemez. Sadece onun kendisine bir zarar vermemesi konusunda temkinli ve tedbirli davranabilir.

\footnotetext{
56 Buhârî, "Sehâdet", 27; "Ahkam", 20.

${ }^{57}$ Şâtıbî, Muvâfakât, 2/267.

58 Şâtıî, Muvâfakât, 2/271.

${ }^{59}$ Buhârî, "Teheccüd", 2; "Ta‘bîr", 35.

60 Şâtıbî, Muvâfakât, 2/267, 273.

${ }^{61}$ Şâtıbî, Muvâfakât, 2/274.
} 
$\mathrm{Bu}$ şekilde olağan dışı bilgi alma yöntemlerine (keşf, ilham ve rüyaya) dayalı elde edilen bilgiler, şer'î hükümlere göre değerlendirilmeden kabul veya ret edilmemelidir. Şer`î kıstaslar nazarında caiz görülür ise bunlar sahih kabul edilebilir. Aksi takdirde bir geçerliliği yoktur. Bundan sadece peygamberlerin durumları istisnadır. Onların rüyalarının vahiyden kaynaklandığı konusunda kesinlik vardır. Tıpkı Hz. İbrahim'in evladını kurban etme konusundaki rüyası ile amel etmesi gibi. ${ }^{62}$ Rüyaların dikkate alınabileceği bir diğer yön ise mubah alanlardır. İnsanın mubah alanda iki şey arasında rüya veya keşf bilgisine göre bir davranışta bulunabileceği belirtilmiştir. Burada şer'î bir aslın çiğnenmesi gibi bir durum yoktur. Buna karşın keşf veya rüya bilgisini dikkate almayıp zahiri hükümlerle amel etmesi ve işlerini buna göre düzenlemesi halinde de bu kimse için bir kınanma veya günah söz konusu olmayacaktır. Bu durum göstermektedir ki, rüya vb. olağan dışı bilgi vasıtaları ile elde edilen bilgiler şer ‘î olarak sakıncalı bir durum taşımasa bile mutlak olarak amel edilmesi zorunlu şeyler değildir. ${ }^{63}$ Hatta bir kişi rüyasında $\mathrm{Hz}$. Peygamberi görse ve ona herhangi bir şeyi emretse bu durumda dahi bunun zorunluluğunun olmadığı belirtilmiştir. Çünkü peygamber rüyası dışında hiç kimsenin rüyası ile şer`î bir hüküm sabit olamaz. İnsana uykusunda bir vacibin veya bir mendûbun yapılmaması emredilse bu emre de uyulmaz. ${ }^{64}$ Zira rüyalardaki karışıklık ve belirsizlikler nedeniyle, peygamber rüyaları dışındaki rüyaların shhhatine hükmedilemez. Bu yüzden rüyalar ne dinî bir hükme esas teşkil edebilir, ne de bir dinî hükmü ortadan kaldırabilir. ${ }^{65}$ Ayrıca rüyanın şerê̂ bir hükme aykırı olmaması hali sadece farz veya haram gibi kesin ve kat'î hükümlerle sınırlı olmayıp, müstehap veya tenzihen mekruh gibi alt derecede yer alan hükümler için de geçerlidir. Yani rüyada görülen veya yapılması istenen şey bu tür hükümlerle çakışsa, yine şer`î hüküm esas alınmalı, rüyanın sonucu veya hükmü terkedilmelidir. ${ }^{66}$

Şu husus tekrar vurgulanmalıdır ki, şer'an yasaklanmış bir şey için rüyada 'şunu yap' denilse yahut şer'an emredilmiş bir şey için rüyada 'bunu yapma' denilse, rüyaların doğruluğu sabit olmadığından bunlarla kesinlikle amel edilmez. Zaten böyle bir şey şer'an bâtıl bir şekilde ortaya çıkmış demektir. ${ }^{67}$ Bu yüzden rüya ile yeni bir şer‘î hüküm konamayacağı gibi, mevcut bir şer'i hükmün de rüya ile

\footnotetext{
62 Şâtıbî, Muvâfakât, 2/279.

63 Sâtıbî, Muvâfakât, 2/272-273.

${ }^{64}$ Ebû Abdillâh Bedrüddîn Muhammed b. Bahâdır b. Abdillâh ez-Zerkeşî, el-Bahru'l-Muhît (Gardaka: Dâru's-Safve, 1992), 1/62-63.

65 İbn Hazm, el-ïhkâm, 7/98.

66 Paçacı, "Rüyâ'nın Delil Değeri ve İstihâre", 122.

67 Şâtıbî, Muvâfakât, 2/273.
}

Turkish Academic Research Review - Türk Akademik Araştırmalar Dergisi 
ortadan kaldırılamayacağına dair ulema arasında ittifak olduğu nakledilmiştir. Bu konuda "Beni rüyada gören, gerçekten beni görmüştür”68 hadisinin de fikıh usulü açısından değerlendirildiğinde Hz. Peygamberin görüldüğü rüyaların şer‘î bir hükme kaynaklık edebileceğine delâlet etmediği özellikle vurgulanmıştır. Zira bu hadiste rüyada görülen suretin (şemâilin) şeytanın ya da nefsin bir aldatması olmayıp Hz. Peygamber'e ait olduğuna işaret olduğu, yoksa bu rüyalar ile şer`î bir hüküm verilmesi amacıyla söylenmediği belirtilmiştir. ${ }^{69}$ Buna göre Hz. Peygamberin görüldüğü rüyalar sadık rüyalar kategorisinde değerlendirilmekle birlikte, bu rüyalarda söylendiği veya öğrenildiği belirtilen şeylerin dahi her zaman doğru çıkmadığı âlimlerce dile getirilmiştir. Zira bu rüyalarda görülen şeylerde bile dinin temel esaslarına uymayan unsurların bulanabildiği görülmüştür. Sonuç olarak her ne kadar şeytanın Hz. Peygamber suretine giremeyeceği vurgulanmış olsa da yaşanan tecrübeler Hz. Peygamberin görüldüğü rüyalara dahi hayal vb. şeylerin karışabildiğini göstermektedir. ${ }^{70}$

Sadık rüyaların çoğunlukla salih kullar tarafından görüleceği şeklinde genel kanaate rağmen bunun tersi de olabilmekte, yani salih kullar rüyada kendilerini şirk üzere yahut içki içmek gibi büyük bir günah üzere görebilmektedir. Diğer yandan inançsız veya günahkar birisi de kendisine müjde olabilecek bir sadık rüya görebilmekte, bu rüya ile iman veya tövbeye yönelebilmektedir. Bazen de rüya görülüp hoşa giden şey bir musibet, hile veya aldatmaca olabilmektedir. ${ }^{71}$ Hatta Bedir savaşı öncesi Mekke'de henüz Müslüman olmamış bazı insanların, Bedir savaşının kaybedileceği, bu savaşta Mekke'nin ileri gelenlerinden bir kısmının öldürüleceğine işaret eden rüyalar gördükleri de bildirilmiştir. ${ }^{72}$

Rüyalarla ilgili tüm bu karışık ve girift durumlar yanında rüyanın hangi etkene dayalı olarak ortaya çıktığının bilinememesi, çoğu zaman gerçek dışı hayallerden oluşması, rüyayı görenin uyandığında onu gördüğü şekliyle hatırlayıp hatırlamadığı, ayrıca görülen şeyin yorumlanmasında isabet edilip edilemeyeceği gibi birçok problem rüyaların güvenilirliğini ortadan kaldırmaktadır. Bu nedenlerle, sağlıklı ve sağlam bir din anlayışında, şer'î hükümlerin ancak Kitap, Sünnet, İcmâ ve Kıyas gibi açık delillere dayanması gerektiği, zira bu delillerin hepsinin insan

${ }^{68}$ Buhârî, "Ta'bîr", 10.

69 Ebû Zekeriyyâ Yahyâ Nevevî, Sahîhi Müslim bi şerhi'n-Nevevî (Kahire: Müessesetü Kurtuba, 2. Basım, 1994), 1/166-167.

${ }^{70}$ Serhendî, Mektûbât. 1/297.

${ }^{71}$ Ahmed b. Ali b. Muhammed İbn Hacer, Fethü'l-bârî (Kahire: Mektebetü's-Selefiyye, ts.), $12 / 381$.

72 Halil Hacımüftüoğlu, "Müfessirlere Göre Rüyalar”, Tarihten Günümüze Tartışmalı İnanç Meseleleri II (Sempozyum Bildirileri), ed. Mehmet Bulğen (İstanbul: Marmara Üniversitesi İlahiyat Fakültesi Vakfi Yayınları 2018), 386-387. 
aklına hitap ettiği ve ortaya konulan hükümlerin de diğer insanlar tarafindan ancak bu şekilde objektif ölçütlerle kontrolünün mümkün olacağı unutulmamalıdır. ${ }^{73}$

\section{Sonuç}

Epistemolojik açıdan bakıldığında dini ilimler içerisinde rüyalara en çok değer verip önemseyen bilim dalının tasavvuf olduğu görülmektedir. Misal âleminde görülmesi ve sembolik bir dile sahip olması nedeniyle rüyaların, tasavvuf ilminin temel konularından birisi haline geldiği söylenebilir. Zira tasavvufun dili de semboliktir, işarete dayalıdır. Tasavvufta rüyaların en azından bir kısmı güvenilir bilgi kaynağı konumundadır. Bu nedenledir ki birçok büyük sûfînin hayatını gördükleri rüyalara göre şekillendirdikleri görülmektedir. Tasavvuf ehline göre rüyaların fonksiyonu yalnızca birtakım gaybî bilgilerin elde edilmesi ile sınırlı kalmamakta, rüyalarda elde edilen bilgilerin amelî hayata yansıdığı da görülmektedir. Makalemizde örneklerini incelediğimiz bir kısım sûfî rüyalarında, ya doğrudan fikhî bir hükme işaret edildiği veya ihtilaflı bir fikhî meselenin Hz. Peygambere veya önde bir gelen sûfîye sorularak çözüme kavuşturulduğu görülmektedir. Bu da rüyayı görenlerin rüyalarında elde ettikleri bilgilere tam bir güven duyduklarını gösterir. Fıkıh usulü açısından değerlendirildiğinde ise sadık rüyalar olarak görülen rüyalardaki işaretlere göre mubah alanlarda amelde bulunulabileceği, kişinin özellikle iyiliğe yönelmeyi ve kötülükten kaçınmayı işaret eden rüyalarla amel edebileceği kabul edilmiştir. Bu konuda da bir zorunluluk bulunmamakta, sadece kişinin kendi tercihi esas olmaktadır. Ancak mevcut olmayan bir hüküm rüyaya dayanılarak bir kural olarak va'z edilemez. Aynı şekilde mevcut şer'î bir hüküm de görülen bir rüya ile değiştirilemez veya iptal edilemez. Bu durum, rüyada peygamber görülmüş olsa ve onun tarafından söylenmiş olsa yahut bir tasavvuf büyüğ̈̈ tarafindan söylenmiş olsa da değişmez. Ayrıca rüyaya dayalı elde edildiği belirtilen bilgilere -velev ki doğru bile olsa- dayanılarak kimse suçlanamaz, itham edilemez veya temize çıkarılmaz. Bu tür uygulamalar ancak zahiri deliller üzerinden yapılabilir. Dini hüküm ve uygulamaların rüyalara göre tespit edilmesi veya değiştirilmesi dinin orijinalliğine, sâfiyetine ve ciddiyetine halel getirecek bir durumdur. Bu açıdan fikıh, hadis ve kelam âlimlerinin genelinin rüyayı bilgi kaynağı olarak görmemeleri oldukça önemli bir husustur. Çünkü bu tavır, dinin tahriften ve bidatlerden korunması açısından büyük önemi haizdir. Son olarak rüyada görülen şeye göre fikhî hüküm belirlemek, bir kişinin sübjektif tecrübesinin esas alınarak İslam âlimlerinin genelinin görüşünün terk edilmesi demektir ki bunun ise kabul edilebilir bir yönü yoktur.

${ }^{73}$ Karadaş, "Rüyanın Mâhiyeti Bilgi ve Hüküm Değeri”, 60.

Turkish Academic Research Review - Türk Akademik Araştırmalar Dergisi https://dergipark.org.tr/tr/pub/tarr 


\section{Kaynakça}

Afîfî, Abdülhakim. Bilimsel ve Dinî Açıdan Rüyalar ve Kâbuslar. çev. Bünyamin Açıkalın. İstanbul: Rağbet Yayınları, 2011.

Akot, Bülent. "Tasavvufî Terbiyede Rüyânın Değeri”. Hitit Üniversitesi Illahiyat Fakültesi Dergisi 10/19 (2011/1), 93-113.

Âmidî, Ebü'l-Hasen Seyfüddîn Ali b. Muhammed. el-İhkâm fì usûli'l-fikh. 4 Cilt. Riyad: Dâru's-Samiî, 2003.

Ayhan, Mehmet. "Bir Rivayet Yöntemi Olarak Fütûhât-1 Mekkiyye'de Rüya İle Hadis Rivayeti”. Marife: Dini Araştırmalar Dergisi (Bilimsel Birikim) 11/2 (2011), 49-76.

Azamat, Nihat. "Üftâde". Türkiye Diyanet Vakfi İslam Ansiklopedisi. 42/282-283. İstanbul: TDV Yayınları, 2012.

Bağdâdî, Ebü'l-Vefầ Alî b. Akīl b. Muhammed. el-Vâzıh fì usûli'l-fikh. thk. Abdullah b. Abdülmüslim et-Türkî. Beyrut: Müessesetü’r-Risâle, 1999.

Beyhakî, Ahmed b. Hüseyn. es-Sünenü'l-kübrâ. 16 Cilt. Beyrut: Dâru'l-Kütübi'lİlmiyye, 2003.

Buhârî, Ebû Abdillah Muhammed b. İsmail. Sahîhu Buhârî. Dimeşk-Beyrut: Dâru İbni Kesîr, 2002.

Bursevî, İsmail Hakkı. Silsilenâme-i Celvetiyye. çev. Rahmi Serin. haz. Arif Pamuk. İstanbul: Pamuk Yayınları, ts.

Bursevî, İsmail Hakkı. Tefsîru rûhi 'l-beyân. 10 Cilt. İstanbul: Matbaatü Osmaniyye, 1330/h.

Çelebi, İlyas. "Rüya". Türkiye Diyanet Vakfi İslam Ansiklopedisi. 35/306-309. Ankara: TDV Yayınları, 2008.

Demir, Abdullah. "Tasavvufta Rüya Tabiri”. USBD Uluslararası Sosyal Bilimler Dergisi 1/9 (2017), 41-49.

Dokgöz, Derviş. Bursevî'nin Rûhu'l-Beyân Tefsirindeki Usûlî ve Fıkhî Görüşleri. Malatya: İnönü Üniversitesi Sosyal Bilimler Enstitüsü, Doktora Tezi, 2020.

Eren, Mehmet.“Sadreddin Konevî’nin Tasavvufî Hadis Şerhçiliği Hz. Peygamber’in Rüyada Görülmesi Rivayeti Çerçevesinde". I. Uluslararası Sadreddin Konevî Seтровуити Bildirileri. 99-115. Konya: Mebkam, 2008. 
Freud, Sigmund. Düşlerin Yorumu. çev. Emre Kapkın. 2 Cilt. İstanbul: Payel Yayınevi, 1996.

Fromm, Erich. Rüyalar Masallar Mitoslar (Sembol Dilinin Çözümlenmesi). çev. Aydın Arıtan-Kaan H. Ökten. İstanbul: Arıtan Yayınevi, 1992.

Gazzâlî, Ebû Hâmid Muhammed b. Muhammed. İhyâu 'ulûmi'd-dîn. Beyrut: Dâru İbn Hazm, 2005.

Hacımüftüoğlu, Halil. “Müfessirlere Göre Rüyalar”. Tarihten Günümüze Tartışmalı İnanç Meseleleri II (Sempozyum Bildirileri). ed. Mehmet Bulğen. 385-405. İstanbul: Marmara Üniversitesi İlahiyat Fakültesi Vakfı Yayınları, 2018.

İbnü'l-Arabî, Ebu Bekir Muhyiddin Muhammed b. Ali. el-Fütûhâtü'l-Mekkiyye. 9 Cilt. Beyrut: Dâru'l-Kütübi’l-İlmiyye, 1999.

İbn Hacer, Ahmed b. Ali. Fethü'l-bârî. 13 Cilt. Kahire: Mektebetü's-Selefiyye, ts.

İbn Haldun, Abdurrahman b. Muhammed. Mukaddime. çev. Halil Kendir. 2 Cilt. Ankara: y.y., 2004.

İbn Hazm, Ebû Muhammed Alî b. Ahmed b. Saîd. el-İhkâm fî usûli'l-ahkâm. 8 Cilt. Beyrut: Dâru'l-Âfâki'l-Cedîde, 1979.

İmamoğlu, Abdulvahit. "Bazı Psikanalistlere Göre Rüyanın İnsan Hayatındaki Rolü”. Sakarya Üniversitesi Ilahiyat Fakültesi Dergisi 12/22 (2010/2), 22-46.

Karadaş, Cağfer. "Rüyanın Mâhiyeti Bilgi ve Hüküm Değeri”. Diyanet İlmi Dergi 3/1 (2017), 43-62.

Kayac1, Murat. Tasavvuf Geleneğinde Rüya. Çorum: Hitit Üniversitesi Sosyal Bilimler Enstitüsü, Yüksek Lisans Tezi, 2018.

Koçoğlu, Turgut. İki Kutup Hüdâŷ̂ Ve Üftâde Bir Eser Vâkl'ât Tercümesi. Kayseri: Laçin Yayınları, 2014.

Kuşeyrî, Zeynülislâm Abdülkerîm b. Hevâzin. Kuşeyrî Risâlesi. çev. Süleyman Uludağ. İstanbul: Dergah Yayınları, 2016.

Küçük, Osman Nuri. “Muhyiddîn İbnü’l-Arabî’ye Göre Rüya ve Tabiri”. Marife: Dini Araştırmalar Dergisi [Bilimsel Birikim] 14/3 (2014), 31-56.

Mekkî, Ebu Talip. Kûtü'l-kulûb. Kahire: Mektebetü Dâru't-Türas, 2001.

Nevevî, Ebû Zekeriyyâ Yahyâ. Sahîhu Müslim bi şerhi'n-Nevevî. 18 Cilt. Kahire: Müessesetü Kurtuba, 2. Basım, 1994.

Turkish Academic Research Review - Türk Akademik Araştırmalar Dergisi https://dergipark.org.tr/tr/pub/tarr 
Öteleş, Zeliha. "Tasavvufun Metafizik Omurgası: Rüya -Fusûs Merkezli Bir Değerlendirme-". Süleyman Demirel Üniversitesi Illahiyat Fakültesi Dergisi 43/2 (2019/2), 139-147.

Özarslan, Selim. Günümüz Kelam İnanç Problemleri. Ankara: Nobel Yayınları, 2016.

Özarslan, Selim. "İslami Kaynaklar Işığında Rüya Konusuna Kelamî Bir Bakış". Diyanet İlmi Dergi 45/4 (2009), 89-108.

Özçelik, Mevlüt. İmam Gazâlî’ye Göre Nefsin Tezkiyesi ve Kalbin Tasfiyesi. Ankara: Sonçă̆ Akademi, 2020.

Özköse, Kadir. "Sûfî Gelenekte Rüya". Somuncu Baba Aylı Ilim - Kültür Ve Edebiyat Dergisi 129 (Temmuz 2011), 26-29.

Paçacı, İbrahim. "Rüyâ'nın Delil Değeri Ve İstihâre". Dini Araştırmalar 19/48 (Ocak-Haziran 2016), 103-128.

Râgıb el-İsfahânî, Ebü'l-Kâsım Hüseyn b. Muhammed. el-Müfredât. thk. Muhammed Seyyid Keylanî. Beyrut: Dâru'l-Ma'rife, ts.

Sâbûnî, Muhammed Ali. Ravâiu'l-beyân tefsîru âyâti'l-ahkâm. 2 Cilt. Beyrut: Müessesetü Menâhilü’l-İrfan, 1980.

Serhendî, Ahmed el-Fârûkî (İmam Rabbânî). Mektûbât. çev. Abdülkadir Akçiçek. 3 Cilt. İstanbul: Dergah Ofset, 1998.

Şâtıbî, Ebû İshak. el-Muvâfakât. çev. Mehmet Erdoğan. 4 Cilt. İstanbul: İz Yayınc1lik, 1999.

Şerkâvî, Hasan. Mu 'cemu elfâzi's-sûfiyye. Kahire: Müessesetü'l-Muhtâr, 1987.

Tahâvî, Ebû Cafer Ahmet b. Muhammed b. Selâme. Şerhu müsskilü'l-âsâr. 16 Cilt. Beyrut: Müessesetü'r-Risâle, 1994.

Uludağ, Süleyman. "Rüya”. Türkiye Diyanet Vakfi İslam Ansiklopedisi. 35/309-310. Ankara: TDV Yayınları, 2008.

Uludağ, Süleyman. "Sefer”. Türkiye Diyanet Vakfi İslam Ansiklopedisi. 36/ 298-299. İstanbul: TDV Yayınları, 2009.

Yılmaz, Hasan Kamil. Ana Hatlariyla Tasavvuf ve Tarikatlar. İstanbul: Ensar Neşriyat, 2015. 
Yılmaz, Hasan Kamil. Aziz Mahmut Hüdâŷ̂. Ankara: Diyanet İşleri Başkanlı̆̆ı Yayınları, 2016.

Yılmaz, Hasan Kâmil "Konevî’de Rüyâ Anlayışı”. I. Uluslararası Sadreddin Konevî Sempozyumu Bildirileri. 237-248. Konya: Mebkam, 2008.

Zerkeşî, Ebû Abdillâh Bedrüddîn Muhammed b. Bahâdır b. Abdillâh. el-Bahru'lMuhît. 6 Cilt. Gardaka: Dâru's-Safve, 1992.

Turkish Academic Research Review - Türk Akademik Araştırmalar Dergisi https://dergipark.org.tr/tr/pub/tarr 